University of Nebraska - Lincoln

DigitalCommons@University of Nebraska - Lincoln

\title{
Microsatellite loci for distinguishing spotted owls (Strix occidentalis), barred owls (Strix varia), and their hybrids
}

\author{
W. Chris Funk \\ U.S. Geological Survey, Chris.Funk@colostate.edu \\ Thomas D. Mullins \\ U.S. Geological Survey, tom_mullins@usgs.gov \\ Eric D. Forsman \\ U.S. Department of Agriculture Forest Service \\ Susan M. Haig \\ U.S. Geological Survey, Susan_Haig@usgs.gov
}

Follow this and additional works at: https://digitalcommons.unl.edu/usgsstaffpub

Part of the Geology Commons, Oceanography and Atmospheric Sciences and Meteorology Commons, Other Earth Sciences Commons, and the Other Environmental Sciences Commons

Funk, W. Chris; Mullins, Thomas D.; Forsman, Eric D.; and Haig, Susan M., "Microsatellite loci for distinguishing spotted owls (Strix occidentalis), barred owls (Strix varia), and their hybrids" (2007). USGS Staff-- Published Research. 687.

https://digitalcommons.unl.edu/usgsstaffpub/687

This Article is brought to you for free and open access by the US Geological Survey at DigitalCommons@University of Nebraska - Lincoln. It has been accepted for inclusion in USGS Staff -- Published Research by an authorized administrator of DigitalCommons@University of Nebraska - Lincoln. 


\title{
PRIMER NOTE
}

\section{Microsatellite loci for distinguishing spotted owls (Strix occidentalis), barred owls (Strix varia), and their hybrids}

\author{
W. CHRIS FUNK, ${ }^{*}$ THOMAS D. MULLINS, ${ }^{*}$ ERIC D. FORSMAN† and SUSAN M. HAIG* \\ *US Geological Survey, Forest and Rangeland Ecosystem Science Center, 3200 SW Jefferson Way, Corvallis, OR 97331, USA, +US \\ Department of Agriculture Forest Service, Pacific Northwest Experiment Station, 3200 SW Jefferson Way, Corvallis, OR 97331, USA
}

\begin{abstract}
We identified four diagnostic microsatellite loci that distinguish spotted owls (Strix occidentalis), barred owls (Strix varia), $\mathrm{F}_{1}$ hybrids and backcrosses. Thirty-four out of 52 loci tested $(65.4 \%)$ successfully amplified, and four of these loci $(\mathbf{1 1 . 8 \%})$ had allele sizes that did not overlap between spotted and barred owls. The probability of correctly identifying a backcross with these four loci is 0.875 . Genotyping potential hybrid owls with these markers revealed that field identifications were often wrong. Given the difficulty of identifying hybrids in the field, these markers will be useful for hybrid identification, law enforcement and spotted owl conservation.
\end{abstract}

Keywords: backcross, $\mathrm{F}_{1}$, hybrid identification, microsatellites, Strix occidentalis, Strix varia

Received 31 July 2006; revision accepted 18 September 2006

The northern spotted owl (Strix occidentalis caurina) is a threatened subspecies under the US Endangered Species Act (ESA) associated with rapidly declining, old forests in western North America (US Fish \& Wildlife Service 1990). An additional threat to northern and California spotted owls (Strix occidentalis occidentalis) comes from competition and hybridization with barred owls (Strix varia), a close relative historically occurring in eastern North America which has rapidly expanded its range westward into that of northern and California spotted owls. Since hybrid owls are not protected under the ESA, it is critical for law enforcement officials to be able to identify pure northern spotted owls, which are legally protected.

As field identification of spotted owl $\times$ barred owl hybrids is difficult, an amplified fragment length polymorphism (AFLP) method was developed for hybrid identification (Haig et al. 2004). A limitation of AFLPs, however, is that they cannot positively distinguish $\mathrm{F}_{1}$ s from backcrosses because they are dominant markers. Distinguishing between $\mathrm{F}_{1} \mathrm{~s}$ and backcrosses is important for determining the nature and extent of hybridization and for making management decisions. In this study, we identified microsatellite markers that distinguish spotted owls,

Correspondence: W. C. Funk, Fax: (541) 758 8806; E-mail: cfunk@usgs.gov barred owls, $\mathrm{F}_{1}$ hybrids and backcrosses because of their codominant inheritance.

We identified diagnostic microsatellite markers using a three-step process. First, we tested which of 52 previously developed candidate loci successfully amplified in a subset of spotted owls $(n=7)$. For those loci that amplified, we then examined allele size variation in a subset of spotted owls $(n=7)$, barred owls $(n=6)$ and $\mathrm{F}_{1}$ hybrids $(n=2)$ to identify potentially diagnostic markers with non-overlapping allele sizes. Finally, we verified that allele sizes did not overlap between spotted and barred owls for these markers using larger samples of spotted owls $(n=49)$, barred owls $(n=29)$ and hybrids $(n=6)$. Spotted owl samples included northern spotted owls (S. o. caurina) from Washington, Oregon and California $(n=10$ from each state); California spotted owls (S. o. occidentalis) from California $(n=10)$; and Mexican spotted owls (Strix occidentalis lucida) from Arizona $(n=9)$. Barred owl samples were from Wisconsin $(n=7)$, Texas $(n=2)$, Washington $(n=4)$, Oregon $(n=12)$, and California $(n=4)$. Hybrids were from Oregon. Owls were identified in the field based on plumage characteristics, vocalizations and/or matings between known parents. We also examined an additional six potential $\mathrm{F}_{1}$ hybrids and potential backcrosses from Oregon $(n=5)$ and Washington $(n=1)$ for which taxonomic status was unresolved by field biologists. 
Table 1 Microsatellite loci for distinguishing spotted owls, barred owls and their hybrids

\begin{tabular}{|c|c|c|c|c|c|}
\hline \multirow[b]{2}{*}{ Locus } & \multirow[b]{2}{*}{ Repeat motif } & \multirow[b]{2}{*}{ Primer sequences $\left(5^{\prime}-3^{\prime}\right)$} & \multirow[b]{2}{*}{$T_{\mathrm{a}}\left({ }^{\circ} \mathrm{C}\right)$} & \multicolumn{2}{|c|}{ Allele sizes } \\
\hline & & & & Spotted owls & Barred owls \\
\hline Bb126 & $(\mathrm{GA})_{15}$ & $\begin{array}{l}\text { F: TCTCCAGAAGGGTTGTCATC } \\
\text { R: TGCTAAAACCTTACAGAATAACAG }\end{array}$ & 45 & 183 & 179 \\
\hline BOOW18 & $(\mathrm{AAAG})_{6}$ & $\begin{array}{l}\text { F: TTCTGCCTTACAGTCTAGT } \\
\text { R: AAAAACCTATCTTTGTGAGT }\end{array}$ & 58 & 203 & $\begin{array}{l}187,193 \\
195,197\end{array}$ \\
\hline Oe045 & $(\text { GATA })_{13}$ GATTA $(\text { GATA })_{10}$ & $\begin{array}{l}\text { F: GTATGTTCTACGTTGGATTTCCA } \\
\text { R: AAACCTGGCAAGTGCTGTT }\end{array}$ & 58 & 125,129 & 113 \\
\hline Oe128 & $(\text { GATA })_{13}$ & $\begin{array}{l}\text { F: CGTTGTAAATGATGAATCGCCTAGTGC } \\
\text { R: ATGCATGTATACATACAAACCTGG }\end{array}$ & 64 & $\begin{array}{l}307,311,315,319 \\
323,327,331\end{array}$ & $\begin{array}{l}287,291 \\
295,299\end{array}$ \\
\hline
\end{tabular}

$T_{a^{\prime}}$ annealing temperature. Repeat motifs are from the original sequenced clones. Bb126 primers are from Isaksson \& Tegelström (2002), BOOW18 primers are from Koopman et al. (2004), and Oe primers are from Hsu et al. (2003; GenBank Accession nos are found in these references). Some alleles at BOOW18 differ in size from each other by increments of two bp in barred owls, indicating the presence of dinucleotide repeats at this locus despite a tetranucleotide repeat motif in the original boreal owl clone.

DNA from blood samples was isolated using standard phenol-chloroform extractions. DNA from muscle, heart and toe pads was isolated using DNeasy Tissue Kits (QIAGEN). The 52 loci initially screened were developed for spotted owls (six loci; Thode et al. 2002), eagle owls (Bubo bubo; seven; Isaksson \& Tegelström 2002), Lanyu scops owls (Otus elegans botelensis; 18; Hsu et al. 2003, 2006), boreal owls (Aegolius funereus; seven; Koopman et al. 2004), burrowing owls (Athene cunicularia; seven; Korfanta et al. 2002), and ferruginous pygmy owls (Glaucidium brasilianum; seven; Proudfoot et al. 2005). Reaction mixtures (10 $\mu \mathrm{L}$ total) for the four diagnostic loci (Bb126, BOOW18, Oe045 and Oe128; Table 1) contained approximately $20 \mathrm{ng}$ of owl DNA, 0.4-0.5 U Taq DNA polymerase (Promega), $1 \mu \mathrm{L} 10 \times$ polymerase chain reaction (PCR) buffer (Promega), $0.5-1 \mu \mathrm{L}$ of $25 \mathrm{~mm} \mathrm{MgCl}_{2}, 0.3-0.5 \mu \mathrm{L}$ of $10 \mathrm{~mm}$ dNTPs, and $0.15-0.2 \mu \mathrm{L}$ of each $20 \mu \mathrm{M}$ primer. The forward primer of each primer pair was fluorescently labeled with FAM or VIC. Thermal cycling conditions included an initial $94^{\circ} \mathrm{C}$ denaturation step for $7 \mathrm{~min} ; 35$ cycles at $94^{\circ} \mathrm{C}$ for $30 \mathrm{~s}$, the appropriate annealing temperature (Table 1) for $45 \mathrm{~s}$, and $72{ }^{\circ} \mathrm{C}$ for $45 \mathrm{~s}$; and a final elongation step at $72{ }^{\circ} \mathrm{C}$ for $6 \mathrm{~min}$. PCR fragments were analysed on an ABI 3100 capillary DNA sequencer and results were processed using $A B I$ GENESCAN and GENOTYPER software.

Thirty-four of 52 candidate loci (65.4\%) successfully amplified using spotted owl DNA. Of these 34 loci, four $(11.8 \%)$ had allele sizes that did not overlap between spotted and barred owls and showed expected genotypes for known $F_{1}$ hybrids and $F_{1} \times$ barred owl backcrosses. Hardy-Weinberg (HW) proportions and linkage disequilibrium (LD) were not tested because many loci were invariant within species (in which case it is not possible to test for HW proportions or LD) and because samples were taken from different populations (in which case deviations from HW proportions and LD are expected even in the absence of null alleles and linkage). Nonetheless, alleles from the parental species segregated independently among loci in the three backcrosses identified, indicating that these loci are likely not tightly linked.

All owls identified as spotted owls in the field were also identified as spotted owls with the diagnostic microsatellite markers and all birds identified as barred owls in the field were confirmed as barred owls (Table 2). Likewise, all birds confidently identified as $\mathrm{F}_{1}$ hybrids or backcrosses in the field were verified with microsatellites. However, five out of six birds identified as potential $\mathrm{F}_{1} \mathrm{~s}$ or backcrosses in the field were identified incorrectly. Of the four birds thought to be potential $\mathrm{F}_{1} \mathrm{~s}$, one was a spotted owl and three were barred owls. The bird identified as a potential $\mathrm{F}_{1} \times$ spotted owl backcross was a pure spotted owl. Only the bird identified as a potential $\mathrm{F}_{1} \times$ barred owl backcross was correctly identified.

With four diagnostic loci, there is a probability of $0.5^{4}=0.0625$ that an $F_{1} \times$ barred owl backcross would only have barred owl alleles at all four loci, and therefore be incorrectly identified as a pure barred owl. The same calculation applies to $\mathrm{F}_{1} \times$ spotted owl backcrosses. There is also a probability of 0.0625 that a backcross would have one allele from each parental species at all four loci, and therefore be incorrectly identified as an $\mathrm{F}_{1}$ hybrid. Thus, the probability of correctly identifying a backcross with four loci is $1-0.0625-0.0625=0.875$. These loci therefore provide a fairly high level of power for identifying backcrosses (as well as a probability of 1.0 of correctly identifying $\mathrm{F}_{1}$ hybrids). Given the difficulty of correctly identifying spotted owl $\times$ barred owl hybrids from plumage, as illustrated above by incorrect field identifications, these markers will play a useful role in hybrid identification and spotted owl conservation. 
Table 2 Identification of spotted owls, barred owls and their hybrids with diagnostic microsatellite markers

\begin{tabular}{|c|c|c|c|c|}
\hline \multirow[b]{2}{*}{ Field identification } & \multicolumn{4}{|c|}{ Microsatellite identification } \\
\hline & Spotted owl & Barred owl & $\mathrm{F}_{1}$ hybrid $(\mathrm{SO} \times \mathrm{BO})$ & Backcross $\left(\mathrm{F}_{1} \times \mathrm{BO}\right)$ \\
\hline Spotted owl & 49 & 0 & 0 & 0 \\
\hline Barred owl & 0 & 29 & 0 & 0 \\
\hline $\mathrm{F}_{1}$ hybrid $(\mathrm{SO} \times \mathrm{BO})$ & 0 & 0 & 4 & 0 \\
\hline Backcross $\left(\mathrm{F}_{1} \times \mathrm{BO}\right)$ & 0 & 0 & 0 & 2 \\
\hline Potential $\mathrm{F}_{1}$ hybrid $(\mathrm{SO} \times \mathrm{BO})$ & 1 & 3 & 0 & 0 \\
\hline Potential backcross $\left(\mathrm{F}_{1} \times \mathrm{BO}\right)$ & 0 & 0 & 0 & 1 \\
\hline Potential backcross $\left(\mathrm{F}_{1} \times \mathrm{SO}\right)$ & 1 & 0 & 0 & 0 \\
\hline
\end{tabular}

$\mathrm{SO}$, spotted owl; $\mathrm{BO}$, barred owl. Potential $\mathrm{F}_{1}$ hybrids and potential backcrosses were owls for which taxonomic status was unresolved by field biologists.

\section{Acknowledgements}

We are grateful to the many people who provided tissue samples for this study. We thank P. Spruell for comments on our manuscript and $P$. Trail for discussions regarding owl hybrids. Funding was provided by the USGS Forest and Rangeland Ecosystem Science Center and the USDA Forest Service Pacific Northwest Research Station.

\section{References}

Haig SM, Mullins TD, Forsman ED, Trail PW, Wennerberg L (2004) Genetic identification of spotted owls, barred owls, and their hybrids: legal implications of hybrid identity. Conservation Biology, 18, 1347-1357.

Hsu Y-C, Severinghaus LL, Lin Y-S, Li S-H (2003) Isolation and characterization of microsatellite DNA markers from the Lanyu scops owl (Otus elegans botelensis). Molecular Ecology Notes, 3, 595-597.

Hsu Y-C, Li S-H, Lin Y-S, Severinghaus LL (2006) Microsatellite loci from Lanyu scops owl (Otus elegans botelensis) and their cross- species application in four species of Strigidae. Conservation Genetics, 7, 161-165.

Isaksson M, Tegelström H (2002) Characterization of polymorphic microsatellite markers in a captive population of the eagle owl (Bubo bubo) used for supportive breeding. Molecular Ecology Notes, 2, 91-93.

Koopman ME, Schable NA, Glenn TC (2004) Development and optimization of microsatellite DNA primers for boreal owls (Aegolius funereus). Molecular Ecology Notes, 4, 376-378.

Korfanta NM, Schable NA, Glenn TC (2002) Isolation and characterization of microsatellite DNA primers in burrowing owl (Athene cunicularia). Molecular Ecology Notes, 2, 584-585.

Proudfoot G, Honeycutt R, Slack RD (2005) Development and characterization of microsatellite DNA primers for ferruginous pygmyowls (Glaucidium brasilianum). Molecular Ecology Notes, 5, 90-92.

Thode AB, Maltbie M, Hansen LA, Green LD, Longmire JL (2002) Microsatellite markers for the Mexican spotted owl (Strix occidentalis lucida). Molecular Ecology Notes, 2, 446-448.

US Fish and Wildlife Service (1990) Determination of threatened status for the northern spotted owl. Federal Register, 55, 26114-26194. 